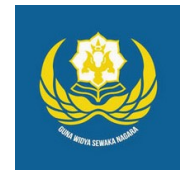

Jurnal Analogi Hukum

Journal Homepage: https://ejournal.warmadewa.ac.id/index.php/analogihukum

\title{
Perlindungan Hukum terhadap Pekerja dalam Perjanjian Kerja Waktu Tertentu Menurut Undang-Undang no 13 Tahun 2003
}

\author{
Ni Putu Nita Erlina Sari*, I Nyoman Putu Budiartha dan Desak Gde Dwi Arini
}

Fakultas Hukum, Universitas Warmadewa, Denpasar, Bali-Indonesia

*erlina.sari@gmail.com

How To Cite:

Sari, N. P. N. E., Budiartha, I. N. P., \& Arini, D. G. D. (2020). Perlindungan Hukum terhadap Pekerja dalam Perjanjian Kerja Waktu Tertentu Menurut Undang-Undang no 13 Tahun 2003. Analogi Hukum. 2(1). 124-128. Doi: http://dx.doi.org/10.22225/.2.1.1613.124-128

\begin{abstract}
In the formation of employment agreements, there are two kinds, namely PKWT and PKWTT. However, in its implementation, the implementation of PKWT carried out by the company is not in accordance with the provisions stipulated in the work agreement and the Manpower Act so that the regulation regarding employment is still stretched various constraints and problems as well as challenges faced and require resolution through the court. Based on these explanations, the researcher raised the formulation of the problem 1) How is the Legal Relationship Between Workers and Companies in a Specific Time Work Agreement (PKWT) According to Law Number 13 Year 2003 and 2) What is the Form of Legal Protection Against Workers in a Specific Time Work Agreement Under the Act Law No. 13 of 2003. This study uses normative research methods. The legal materials used are primary, secondary. Work relations that occur between workers and employers are based on an employment agreement as explained by Article 50 of Law Number 13 Year 2003 Regarding Employment. In addition, PKWT can also be updated if the company so wishes.
\end{abstract}

Keywords: PKWT, Legal Protection, Outsourcing

Abstrak-Dalam pembentukan perjanjian ketenaga kerjaan, terdapat dua macam yaitu PKWT dan PKWTT. Namun dalam pelaksanaanya, penerapan PKWT yang dilaksanakan oleh perusahaan ada yang tidak sesuai dengan ketentuan yang diatur dalam perjanjian kerja dan Undang-Undang Ketenagakerjaan sehingga pengaturan mengenai ketenagakerjaan masih terbentang berbagai kendala dan masalah serta tantangan yang dihadapi dan memerlukan penyelesaian melalui pengadilan. Berdasarkan penjelasan tersebut maka peneliti mengangkat rumusan masalah 1) Bagaimanakah Hubungan Hukum Antara Pekerja Dengan Perusahaan dalam Perjanjian Kerja Waktu Tertentu (PKWT) Menurut Undang-Undang Nomor 13 Tahun 2003 dan 2) Bagaimana Bentuk Perlindungan Hukum Terhadap Pekerja dalam Perjanjian Kerja Waktu Tertentu Berdasarkan UndangUndang Nomor 13 tahun 2003. Penelitian ini menggunakan metode penelitian normatif. Bahan hukum yang di gunakan yaitu primer, sekunder. Hubungan kerja yang terjadi antara pekerja dan pengusaha didasarkan atas perjanjian kerja seperti yang dijelaskan oleh Pasal 50 Undang-Undang Nomor 13 Tahun 2003 Tentang Ketenagakerjaan. Selain itu, PKWT juga dapat diperbarui apabila perusahaan menghendaki.

Kata Kunci: PKWT, Perlindungan Hukum, Outsourcing

\section{Pendahuluan}

Manusia dalam memenuhi kebutuhan hidupnya melakukan suatu pekerjaan, dalam bekerja kita butuh suatu peristiwa yang melibatkan orang lain untuk berinteraksi agar dapat memberikan hasil berupa uang atau jasa untuk memenuhi kebutuhan hidup sehari-hari (Abdussalam, 2009). Manusia dalam berinteraksi satu dengan yang lainnya akan menimbulkan suatu peristiwa dalam masyarakat, yang akibatnya diatur oleh hukum itulah yang disebut dengan peristiwa hukum.

Reformasi merupakan perubahan yang mengubah sesuatu atau suatu sistem pada suatu masa. Indonesia merupakan negara yang sangat luas dan diisi oleh ribuan ragam suku bangsa, Indonesia sendiri tidak lepas dari yang namanya Reformasi yakni tahun 1998 puncak dari pada 
perubahan iklim politik dan ekonomi di negara ini. Gerakan-gerakan yang diplopori oleh mahasiswa sebagai akademisi dengan berlandaskan rasa perjuangan terhadap dzalimnya pemerintahan di masa itu menimbulkan gejolak nasional dan mengubah wajah pemerintahan Indonesia hingga saat ini (Agusmidah, 2010).

Sifat privat yang ditandai adanya hubungan kerja sudah diatur dalam Pasal 50 UndangUndang No. 13 Tahun 2003 tentang Ketenagakerjaan yang menegaskan bahwa: Hubungan kerja terjadi karena adanya perjanjian kerja antara pengusaha dan pekerja/ buruh. Pasal di atas menerangkan perjanjian kerja merupakan awal dari lahirnya hubungan kerja antara pengusaha dengan pekerja/ buruh dengan substansi perjanjian yang dibuat tidak boleh bertentangan dengan peraturan perundang -undangan. Perjanjian kerja memiliki aturan yang sudah ada sedaridulu yang pada dasarnya, memilkiki aturan-aturan tersendiri kepada setisap pelaku pembuat perjanjian. Perjanjian kerja memiliki pemahamannya sendiri, yang pada prinsipnya memiliki sifat secara terbuka olehkarena itu segala jenis perjanjian, dalam pembentukan perjanjian ketenaga kerjaan memiliki dua macam yaitu PKWT dan PKWTT (Djumadi, 2006).

PKWT memiliki arti perjanjian pekerja waktu tertentu yang hanya berlaku satu atau dua tahun dan setelah itu tergantung dengan perjanjian apakah akan dilanjtkan atau tidkanyan oleh pengusaha atau atasan sedangkan PKWTT yaitu perjanjian kerja waktu tidak tertentu, memiliki masa perjanjian yang cukup lama. Perjanjian seperti ini cukup membuat pengusaha sangat menjamin, perjanjian kerja dengan waktu Namun, penerapan PKWT yang dilaksanakan oleh perusahaan ada yang tidak sesuai dengan ketentuan yang diatur dalam perjanjian kerja dan Undang-Undang Ketenagakerjaan sehingga pengaturan mengenai ketenagakerjaan masih terbentang berbagai kendala dan masalah serta tantangan yang dihadapi dan memerlukan penyelesaian melalui pengadilan. Penerapan dalam pasal tersebut tidak terlaksana dengan baik dalam hal jenis pekerjaan yang tidak sesuai dengan pekerjaan yang diperjanjikan, masa jangka waktu kerja dan jeda waktu tunggu. Hal tersebut ditemukan ada beberapa masalah tentang status pekerja yang sudah melebihi masa kontrak 3 (tiga) tahun (Halim, 1987). Pertama, seorang pekerja yang bekerja di sebuah perusahaan yang bergerak di bidang jasa dan telah bekerja selama 10 (sepuluh) tahun, setiap tahunnya setelah habis masa kontrak pekerja harus menandatangani kontrak baru untuk tetap bekerja dan tidak ada informasi dari perusahaan untuk pengangkatan menjadi karyawan tetap.

Sebagaimana telah diuraikan diatas, sebagai acuan dalam pembahasan nanti adapun penelitian ini terbatas pada Hubungan Hukum Antara Pekerja Dengan Perusahaan dalam Perjanjian Kerja Waktu Tertentu (PKWT) dan Bentuk Perlindungan Hukum Terhadap Pekerja dalam Perjanjian Kerja Waktu Tertentu Berdasarkan Undang-Undang Nomor 13 tahun 2003.

\section{Metode}

Penulisan penelitian ini menggunakan penelitian hukum normatif, yang dalam hukum normatif memiliki arti yakni mengkaji bahanbahan yang berasal dari berbagai peraturan perundang-undangan dan menggunakan bahan lain dari berbagai literature tertulis. Penelitian perpustakaan atau pun studi dokumen meniti beratkan pada lebih banyak dilakukan terhadap data yang bersifat sekunder yaitu sifat yang mutlak yang harus dipenuhi dan yang ada tertulis dalam studi dokumen. Pendekatan yang diaplikasikan adalah dengan pendekatan undang -undang, konseptual dan kasus dalam kajian ini mencoba untuk menguat substansi isi putusan yang dipergunakan oleh hakim dalam memutus perkara perjudian di masyarakat sehingga dapat disimpulkan dan dikaitkan dengan sistem normatif yang berlaku. Jenis penelitian yang digunakan yaitu penelitian normatif maka penelitian yang digunakan adalah dengan pendekatan Undang-Undang (Statue Approach) dan bahan lain dari berbagai literature tertulis (Lubis, 1994). Dengan kata lain penelitian ini menggunakan atau meneliti bahan pustaka atau data sekunder. Nilai ilmiah suatu pembahasan masalah terhadap legal issue yang akan diteliti sangat tergantung kepada cara pendekatan yang digunakan, dalam penelitian ini adalah pendekatan Undang-Undang. Jika cara pendekatan tidak tepat, maka penelitian tidak akurat dan kebenarannya pun dapat diragukan sehingga keluaran penelitian tersebut tidak dapat dipertanggungjawabkan.

Penelitian ini mempergunakan bahan hukum yang berdasarkan perundang-undangan, bahan ini diperoleh dari norma-norma atau kaidah-kaidah dasar yaitu Undang-Undang Nomor 13 Tahun 2013 Tentang Ketenagakerjaan. Bahan hukum sekunder yaitu bahan yang memberikan penjelasan mengenai bahan hukum primer, yang digunakan terutama pendapat ahli hukum, hasil penelitian hukum, hasil karya ilmiah dari kalangan sarjana hukum. 
Bahan hukum tersier, yaitu bahan hukum yang digunakan untuk memberikan penjelasan baik bahan hukum primer maupun bahan hukum sekunder seperti Kamus Bahasa Indonesia, Kamus hukum dan lain-lainnya.

Teknik pengumpulan bahan hukum yang dipergunakan dalam penulisan juenal ini yaitu dengan cara membuat catatan-catatan baik berupa kutipan langsung maupun tidak langsung yang diperoleh dari buku-buku, internet atau bacaan-bacaan yang berkaitan dengan permasalahan yang dibahas. Analisis bahan hukum dalam penelitian ini dilakukan secara kualitatif, adalah analisis yang memiliki sifat deskritif yaitu menjelaskan, menguraikan, serta menggambarkan bagian isi penelitian.

\section{Hasil dan Pembahasan}

\section{Hubungan Hukum Antara Pekerja Dengan Perusahaan dalam Perjanjian Kerja Waktu Tertentu (PKWT) Menurut Undang - Undang Nomor 13 Tahun 2003}

Hukum adalah ilmu yang mempelajari tentang aturan-aturan yang berlaku di dalam masyarakat, yang harus ditaati oleh masyarakat itu sendiri dan memiliki sifat yang memaksa agar menaati aturan hukum tersebut. Sebagai Aparat penegak hukum wajiblah menegakkan hukumnya menegakkan hukum tersebut, hukum sendiri memiliki fungsinya yaitu secara tidak langsung pula hukum akan memberikan perlindungan pada tiap hubungan hukum atau segala aspek dalam kehidupan masyarakat yang diatur oleh hukum. Perlindungan yang diberikan hukum kepada masyarakat merupakan perlindungan yang sangat luas yang menjamin kesejahteraan masyarakat yang selalau berpedoman kepada pancasila. Setiap orang berhak mendapatkan perlindungan dari hukum.

Wajib bagi pemerintah untuk memberikan perlindungan kepada seluruh hubungan hukum yang dilakukan masyarakat. Oleh karena itu muncul dan berkembang istilah perlindungan hukum. Pekerja lebih sering dikaitkan dengan diksi Buruh yang dipergunakan pemberi kerja dan sangat populer dalam keilmuaan terkait ketenagakerjaan atau perburuhan.

Perjanjian kontrak kerja untuk pekerja PKWT memang dapat diperpanjang atau diperbaharui. Akan tetapi, terdapat batasan waktunya. Perjanjian kontrak kerja tersebut berlaku paling lamanya dua tahun dan hanya boleh diperpanjang setiap satu kali untuk jangka waktunya maksimal setahun (Kosidin, 1999).
Selain itu, perjanjian kerjanya waktu tertentu juga dapat diperbarui apabila perusahaan menghendaki. Jangka waktu maksimal pembaruan PKWT adalah maksimal dua tahun dan hanya dapat dilakukan sekali. Hal ini sesuai dengan ketentuan Pasal 59 ayat (3), (4) dan (6) Undang-Undang Ketenagakerjaan.

Pekerja kontrak dalam pengertiannya hanya pekerja sementara yang sudah di atur, diamana adanya kesepakatan dalam kontrak kerjanya yang disepakati oleh atasan dan bawahnnya dan jika sewaktu waktu terdapat pemutusan kontrak yang merugikan salah satu pihak makasebaiknya di selesaikan secara kekeluargaan atau dengan hukum yang berlaku. Biasanya pada saat masa kontra akan habis, para karyawan pekerja waktu tertentu atau PKWT meminta kesempatan agar terjalinnya suatu kontrak kerja lagi mengingat mereka juga membutuhkan pekerjaan tersebut.

\section{Bentuk Perlindungan Hukum Terhadap Pekerja dalam Perjanjian Kerja Waktu Tertentu Berdasarkan Undang-Undang Nomor 13 tahun 2003}

Apabila perusahaan tidak ada mempergunakan perjanjian tertulis yang dibuat bersama pekerja maka pihak peruasahaan atau pengusaha dapat dituntut untuk terus memberikan pekerjaan pada pekerja/ buruh sehingga hubungan kerja berubah menjadi hubungan kerja untuk waktu tidak tertentu (PKWTT) yang dikenal dengan pekerja/ buruh tetap. Hal ini dijabarkan dalam Pasal 57 ayat (1) dan (2) UU Ketenagakerjaan. Perjanjian kerja harus di buat secara tertulis dan wajib untuk nantinya akan disepakati oleh kedua belah pihak. Proses pembentukan perjanjian kerja diperlukannya syarat tertentu, dimana syarat tertentu tersebut harus mengikuti peraturan dan atau aturan perundang-undangan yang sesuai dengan tata cara pembuatan perjanjian kontrak yang saling menguntungkan bagi pengusaha dan buruh, pekerja tetap akan memiliki haknya agar memperoleh upah dan penghidupan yang layak tanpa membedakan jenis kelamin (gender), agama, suku, ras (SARA) yang sesuai dengan minat dan kemampuan buruh atau tenaga kerja yang bersangkutan termasuk perlakuan yang didapat yang sama terhadap penyandang cacat(disabilitas) yang mana hal tersebut merupakan pengertian dari perlindungan hukum kepada tenagakerja (Maimun, 2007). Tempat berlindung, perbuatan melindungi, pertolongan dan penjagaan merupakan aspek penting dalam perlindungan tenaga kerja di Indonesia. 


\section{Simpulan}

Ikatan pekerjaan yang membutuhkan satu dengan yang lain antara atasan (pengusaha) dan bawahan (buruh) yang memiliki ikatan perjanjian kerja seperti yang dijelaskan sebelumnya, dalam perjanjian kerja diisikan persetujuan dan kesepakatan antara pengusaha dan buruh untuk saling mengikatkan diri yaitu antara pekerja dan atasan yang saling memerintah dan menerima upah atau gaji yang sesuai dengan upaya-upaya atau kegiatan kerja serta hak dan kewajibanya kedua belah pihak baik yang dibuat tertulis maupun lisan, dalam menjalankan pekerjaanya para pekerja memiliki tetap saja memiliki hak yang memperoleh kesejahteraan hidup yang layak bagi keluarganya, seperti haknya dalam memperoleh jaminan sosial tenaga kerja yang merupakan program pemerintah BPJS Ketenagakerjaan dan berhak memperoleh perlindungannya yaitu keselamatan kerja dalam menjalankan dan menyelesaikan kewajibannya sebagai pekerja, moralnya dan kesusilaannya dan kewajibannya para pekerja yaitu memberikan hasil produksinya yang baik, mengikuti perintah dan tata tertib yang telah ditentukan perusahaan.

Perlindungan hukum dan pelaksanaan perjanjian kerja terhadap tenaga kerja belum sepenuhnya berjalan dan sesuai dengan Peraturan Perundang-Undangan yang berlaku dalam hal ini adalah Undang-Undang Nomor 13 Tahun 2013. Pada Bank Sinar Mas tidak diberlakukannya cuti haid yang menyebutkan bagi wanita yang pada masa setiap dating masa menstruasinya tidak wajib bekerja karena merasakan sakit haid pada hari pertama dan hari kedua masa haid yang dengan hanya memberitahukan kepada penananggungjawab pekerja, tetapi pada Bank Sinar Mas terutama pekerja perempuan yang memasuki masa haid atau merasakan sakit pada masa haid wajib bekerja dan menjalankan tugasnya dengan baik, jikalau pekerja wanita akan mengajukan ijin atau tidak bekerja maka pekerja perempuan tersebut harus menulis surat keterangan dokter dari fasilitas kesehatan atau dokter umum lainnya atau surat keterangan sakit yang menegaskan bahwa pekerja dari perusahaan tersebut tidak bekerja dikarenakan sakit.

Pengaturan PKWT sangat perlu diarahkan agar terciptanya keharmonisan dan kepastian hukum baik secara tertulis maupun dalam penerapannya dan dalam Undang-Undang Nomor 13 Tahun 2013 Tentang Ketenagakerjaan telah cukup memberikan perlindungan hukum bagi Tenaga Kerja Kontrak (PKWT). Alangkah lebih baik direvisi ketentuan mengenai Pekerja Kontrak Untuk Waktu Tertentu (PKWT) dalam KepMen No.100 tahun 2004 Tentang Ketentuan Pelaksanaan Perjanjian Kerja Waktu Tertentu agar lebih jelas dan rinci substansi yang diatur di dalamnya, agar mempermudah dan memperjelas;

Bagi perusahaan khususnya dalam hal pemenuhan dan penjalanan atas hak-hak bagi pekerja. Apabila perjanjian kerja yang dibuat antara pihak pekerja dan Bank Sinar Mas telah dijalankan dengan baik dan benar serta sesuai dengan Peraturan Perundang-Undangan yang berlaku agar hal tersebut terus dilaksanakan sebaik-baiknya dan ditegakan serta diberikan upaya untuk hak-hak dan kewajiban-kewajiban pekerja tetap dipenuhi dan terciptanya suasana kerja yang efektif, nyaman dan kondusif serta saling menguntungkan antara pekerja dan perusahaan;

Masyarakat sebagai pekerja dan atau buruh harus lebih jeli untuk melihat dan memahami isi dari perjanjian mengenai perjanjian kerja waktu tertentu (PKWT) yang disiapkan oleh perusahaaan dimana akan bekerja. Masyarakat pula sebaiknya harus waspada akan penipuan dalam perjanjian kerja tersebut, agar kemudian hari bagi masyarakat sebagai pekerja tidak ada yang merasa dirugikan begitu pula perusahaan akan berjalan dengan baik. Penting kewaspaan masyarakat dalam proses penandatanganan kontrak kerja, pekerja harusa sadar akan hakhak sebagai pekerja serta kewajibannya begitu pula dari perusahaan sebagai pemberi pekerjaan.

\section{Daftar Pustaka}

Abdussalam, H. R. (2009). Hukum Ketenagakerjaan (Hukum Perburuhan) yang telah direvisi. Jakarta: Restu Agung.

Agusmidah. (2010). Dinamika Hukum Ketenagakerjaan Indonesia. Medan: USU Press.

Djumadi. (2006). Hukum Perburuhan Perjanjian Kerja. Jakarta: PT. Raja Grafindo.

Halim, R. (1987). Sari Hukum Perburuhan. Jakarta: PT. Pradnya Paramita.

Kosidin, K. (1999). Perjanjian Kerja Perjanjian Perburuhan dan Peraturan Perusahaan. Bandung: Mandar Maju.

Lubis, M. S. (1994). Filsafat Ilmu dan Penelitian. Bandung: Mandar Maju.

Maimun. (2007). Hukum Ketengakerjaan Suatu 
Pengantar. Jakarta: PT. Pradnya

Paramita. 